\title{
中道 實著
}

\section{『社会調査方法論』}

(恒星社厚生閣，1997年，B5 判，436頁，4,700円)

稲葉 昭英

(東京都立大学専任講師)

社会調査法に関する著作はわが国でも少なくないが，多くは編者・共著という 形をとっている。扱うべき問題が多岐にわたることがその原因であるが，この結 果として全体のバランスや一貫性に問題を抱えるものが少なくない。そんな中で 本書は単著として刊行された, 社会調査法について体系的なテキストである。ま ずは圧巻ともいうべき 400 頁を超えるこの大著を単独でまとめあげた著者の熱意 と努力に敬意を表したい。

本書の目的について著者は「社会調査の『よき』実践者，日常生活手段として 調査を知的に評価しうる『確かな』消費者への道筋を用意する」ことにあるとし， 基本的にはビギナーの読者を想定しているが，専門研究者にとっても十二分に有 用な内容となっている。全体の構造は，まず序章「日常生活と社会調査」で社会 調査を科学方法論の中で位置づ，倫理の問題について解説することから出発す る。以下に続く 12 の章は1「調査問題の決定過程」，2「仮説構成の論理と実際」, 3 「調査設計の選択」，4「測定の論理と評価」，5「尺度の作成」，6「実験」，7「サ ーベイ・リサーチ」，8「フィールド・スタディ」，9「標本の抽出と推定」，10「デ ータの整理とコーディング」, 11 「データの分析一仮説の検定一」, 12 「゙ータの 分析一関係·予測·因果一」から構成されている。この構成からもわかるように, 仮説構築法, 尺度構成法, 心理学的な実験法, 社会学的な標本調査法, 人類学的 な事例法，標本抽出法，統計解析法など多岐にわたる研究法が収録されている。 また随所にKJ法, グラウンデッドセオリー, 三角測量, TDMをはじめとした社 会調査に関する広汎なテクニックや方法がとり込まれており，教養的な知識も十 分得ることができる。内容が多岐にわたるにもかかわらず，各章間の関連は明確 で, 全体が非常に一貫したものとして構成されており, 単著のもつ強みが最大限 に生かされているといえるだろう。

さて，本書は類書に見られないいくつかの特色を持っている。まず $4 \cdot 5 \cdot 6$ 章 で心理学的な測定法，実験法についての解説が非常に丁寧になされていること。 この結果としてサーベイリサーチやフィールドスタディのデザインや特性を実験 法との対応の上で位置づけることが可能になっている。心理測定法についてここ まで詳述し，社会調査法と関連付けた試みはおそらく初めてではないだろうか。 つぎに社会調査においてはノンパラメトリックな方法を用いることが実際的であ るとし，これを詳述していること。統計学的方法についての紙数はそれほど多く 
はないが，12章ではクロス表の解析を中心にノンパラメトリックな方法が論じら れる。ここまでノンパラメトリックな方法を前面に出して解説する試みも類書に は少ない（同章のエラボレイションの方法についての詳細な説明も一読に值する）。 このような労作に注文をつけることは心苦しいが，感じたことをあえて記したい。 (1) 章によって難易度に差があることは否めない。とくに9章の各種標本抽出法と パラメー夕推定の議論はかなり難しい。同時に母平均の推定などの公式に有限修 正を用いているのも本書の特徵であるが, これも結果として一般的な統計学のテ キストとの差異を大きくしており，ビギナーにとっては辛いかもしれない。仕方 のないことではあるが11・12章では本書では触れられていない確率分布の知識を 前提としている部分があり，やはりビギナーにとっては辛いように思われる（こ れ以上本を厚くするのも無理なのだが)。(2) わが国の研究者による実例が取り上 げられてもよかったのではないかと思う。仮説構築にせよ, 統計解析にせよ, 方 法の学習とその実際の応用との間には距離があり, これが社会調査法に関する教 育の最大の障害となっている。最近の心理学のテキストでは研究者による実例を 取り上げて成果をあげているものもあり，このように感じた。(3) 細かいことだが, 2 章の分析単位の議論について。近年, デー夕を測定・観察する単位として測定 (観察) 単位, 結果を説明する単位として説明単位を措定する立場がある。著者の 分析単位の概念は前者に近い印象を受けたが，2つの概念を用いてさらに整理でき ないだろうか。

とはいえ,これらの指摘は「あえていうならば」という類のもので, ‘本書が優 れたテキストであることを否定するものではない。本書を通読してみて, 心理学 にまでおよぶ著者の調査法に関する膨大な知識には驚かされるが，それ以上に感 じるのはデー夕に対する誠実さ，分析に対する真摰な姿勢である。流行の解析法 を追いかけてデー夕に対する誠実さが失われることはこの分野では多々あること であるが, 著者からはそんな姿勢は微塵も感じられない。願わくば, 廉価版が刊 行されることを望みたい。

坂本佳鶴惠著

\section{『〈家族〉イメージの誕生一一日本映画にみる〈ホームドラマ〉 の形成』}

(新曜社，1997年，四六判，412頁，3,600円）

坂岡庸子

(久留米大学教授)

80 年代, 家族内人間関係の解体が社会問題となり, 学会では家族の関係性の変 化や個人化が新たなテーマとなり，90年代には，「フッーの家庭のフッーの子や夫， 